\title{
DEGRADATION OF MIX HYDROCARBONS BY IMMOBILIZED CELLS OF MIX CULTURE USING A TRICKLE FLUIDIZED BED REACTOR
}

(Annual Progress Report)

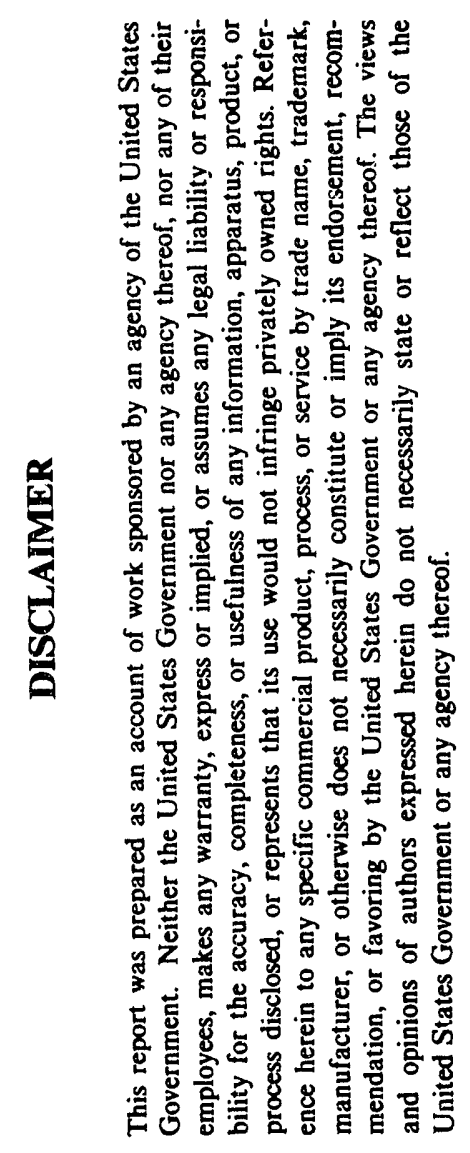

PEC:

JUA 21 \%

Kirit D. Chapatwala, Ph.D.

$\mathrm{OC}$

\author{
Division of Natural Sciences \\ Selma University \\ Selma - Alabama - 36701
}

June 1992 - May 1993

Prepared for the

U.S. Department of Energy

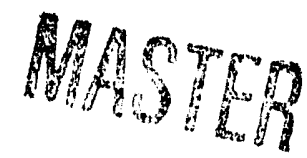

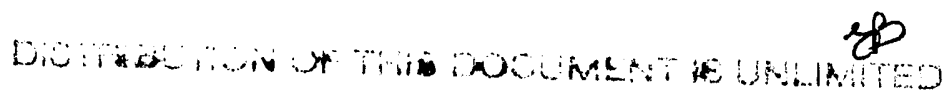




\section{Summary}

The microorganisms, capable of degrading mix hydrocarbons were isolated from the soil samples collected from the hydrocarbon contaminated sites. The mix cultures were immobilized in calcium alginate solution in the form of beads. A trickle fluidized bed air-uplift-type reactor designed to study the degradation of mix hydrocarbons was filled with $0.85 \%$ normal saline containing the immobilized cells of mix culture. The immobilized beads were aerated with $\mathrm{CO}_{2}$-free air at $200 \mathrm{ml} / \mathrm{min}$. The degradation of different concentrations of hydrocarbons in the presence/ absence of commercially available fertilizers by the immobilized cells of mix culture is now in progress. 
Chemicals:

All chemicals, such as Benzene, Xylene, Toluene, Sodium Alginate etc., were obtained from sigma Chemical Company, st. Louis, MO.

Isolation of Mix Cultures:

Different soil samples around industrial sites contaminated with hydrocarbons were collected, stored in polyethylene bags and transported to the laboratory on ice. The mix cultures were isolated from the contaminated soil samples by an enrichment culture techniques using the phosphate buffer medium (PBM) which consists of the following $(g / L): \mathrm{K}_{2} \mathrm{HPO}_{4}, 4.3 ; \mathrm{KH}_{2} \mathrm{PO}_{4}, 3.4 ;\left(\mathrm{NH}_{4}\right)_{2} \mathrm{SO}_{4}, 2.0 ;$ Mg $\mathrm{Cl}_{2} \cdot \mathrm{H}_{2} \mathrm{O}, 0.3 ;$ amended with $0.5 \mathrm{ml}$ of a trace element solution containing (mg/L), $\mathrm{MnCl}_{2} \cdot 4 \mathrm{H}_{2} \mathrm{O}, 1.0 ; \mathrm{FeSO}_{4} \cdot 7 \mathrm{H}_{2} \mathrm{O}$, $\left.0.6 ; \mathrm{CaCl}_{2}\right), 2.6$; and $\mathrm{NaMoO}_{4} \cdot 2 \mathrm{H}_{2} \mathrm{O}, 6.0$.

A 1:10 dilution of each soil sample was made with sterile PBM and the suspension was incubated at room temperature for $1 \mathrm{~h}$. One $\mathrm{ml}$ of the suspension was then transferred into tubes, containing $9 \mathrm{ml}$ of sterile PBM. Different concentrations of hydrocarbons (BTEX) ranging from $2 \mathrm{mM}-1000 \mathrm{mM}$ were then added. The tubes were then incubated at $25^{\circ} \mathrm{C}$. After 7 days of incubation, the tubes were examined for turbidity. A loopful of the turbid sample was 
also streaked onto PBM agar plates (1.5\% Difco Agar) containing BTEX for the identification of mix cultures.

Growth of Mix Cultures:

The mix cultures which were isolated from the contaminated soil samples were grown in large quantities in fermenter. When the cell growth was attained $1.0 \mathrm{OD}$, the cells were centrifuged at $10,000 \times \mathrm{g}$ for $10 \mathrm{~min}$ at $5^{\circ} \mathrm{C}$. The pellet thus obtained were suspended in $0.85 \%$ normal saline.

Immobilization of Mix Cultures in Sodium Alginate:

Equal volumes of cell slurry and sterile $4 \%$ sodium alginate solution were mixed together. The alginate-cell mixture was added dropwise to cold $0.2 \mathrm{M} \mathrm{CaCl}_{2}$ solution. Each drop was hardened into a bead containing entrapped cells of mix culture. The beads were allowed to harden further in $\mathrm{CaCl}_{2}$ solution for $24 \mathrm{~h}$ at $5^{\circ} \mathrm{C}$ in a refrigerator.

Degradation of Mix Hydrocarbons:

The degradation of mix hydrocarbons is being monitored in the air-uplift-type reactor. The reactor was filled with normal saline $(0.85 \%)$ containing the immobilized beads of mix culture. The beads are being aerated with $\mathrm{CO}_{2}$-free air from the bottom of the reactor. The mix hydrocarbons are being mixed with commercially available fertilizers such as 
ammonia, nitrate, nitrite for nitrogen and ortho-phosphate for phosphorus) in normal saline to enhance the degradation. The degradation of the hydrocarbons in the presence/absence of the commercially available fertilizers is being monitored in the samples collected from aqueous sample port at regular intervals. The experiment is in progress and the preliminary results will be available within a month. 

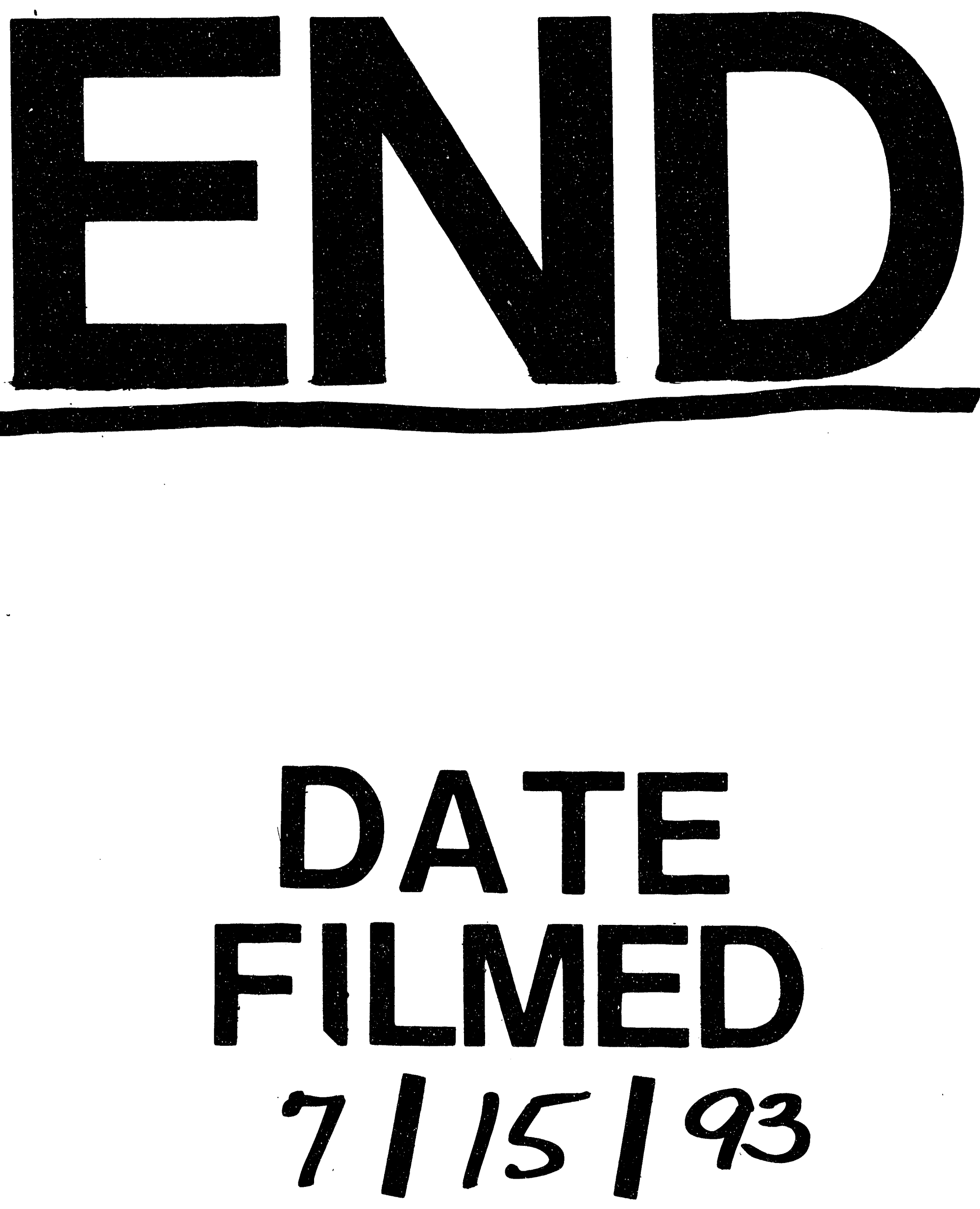
